\title{
Refugee status as a productive tension
}

\author{
TRANSNATIONAL LEGAL THEORY 6(2), 2015
}

PN4@SOAS.AC.UK

\begin{abstract}
Who is an Afghan refugee in Pakistan? The paper delves into this question through a detailed discussion of the concrete mechanisms that contextually define who an Afghan refugee in Pakistan is. Drawing on an understanding of law as generatively irresolute, the paper is concerned with the conditions under which refugee status comes into being is maintained and transformed. The study, first, advances a conceptualisation of refugee status as a productive tension between the content of law and its "excesses", i.e. the multi-scalar meanings and practices that are an integral aspect of refugee status recognition, but that cannot be fully absorbed or contained by law. Second, it highlights contributions that such conceptualisation can offer to refugee legal scholarship and its exclusive concern with state-centred understandings of the refugee. It also intervenes in Foucaultian legal scholarship's debates on the relation between law and disciplinary modalities of power, insisting on a theorisation of law that is firmly grounded in context.
\end{abstract}

Keywords: Refugee status - productive power - Foucault - law and discipline - Afghan Refugees in Pakistan

\section{Introduction}

Identifying who is a refugee is a foundational element of any study concerned with forcibly displaced persons and their international legal protection ${ }^{*}$. This process, however, is marred by several operational and conceptual problems. The difficult task of "counting" recognised refugees and its "politics", discrepancies between international, regional and national refugee definitions, as much as various recognised refugee sub-categorisations, all lead to diverging interpretations and taxonomies (Crisp 1999). The case of Afghans in Pakistan, the empirical setting of this article, seems to magnify these problems. Contentious claims over their numbers and identification have been common ever since their first wave of mass displacement in 1979, but more recent statistics (Kronenfeld 2008: 44) render such controversies overtly paradoxical. The number Afghan refugees repatriated from Pakistan since 2001 exceeds by half a million the number of those who were thought to be residing there in the first place. Who is an Afghan refugee in Pakistan?

The traditional and, according to many, most accurate answer to this question should refer to the content of law, with account taken also of the practice and procedures of the various bodies established by the international community (Goodwin-Gill 1996). Indeed, it is law and those who wield it, which sanctions who is a refugee and who is not, as refugees can only be considered such after a legal recognition of their protection needs. As a consequence, most refugee scholarship approaches the above question by reference to the sources of law and their "correct" implementation by relevant authorities. In so doing, however, such scholarship reproduces the state-centred "conceptual grid" that law projects over the process of migration (cf. Shamir 2001). According to the 1951 UN Convention on Refugees and Stateless Persons $^{2}$, in fact, a refugee is a person with a nationality, but without the protection of the state to which he/she belongs, that finds him/herself outside the sovereign territory of that

\footnotetext{
* Paolo Novak, Lecturer in Development Studies, SOAS, University of London

${ }^{2}$ The most important codification of the refugee definition; see UNHCR (2005) for the exact definition contained in the above Convention.
} 
country. Refugees are peoples in excess of the aspired unity between nation, state and territory and constitute a problem for the interstate system. Refugee law "solves" such problem by granting these persons the opportunity to seek, and possibly obtain, international legal protection when a state fails to do so, institutionally capturing those excesses within the inter-state system. The refugee definition affirms the nation/state/territory ensemble 'as the hierarchical imperative to life activities, [and as the] narrative of modern political life' (Soguk 1999: 18).

Un-fortunately, such state-centred institutional grid does not offer an analytically accurate representation of the multi-scalar social context in which refugee migration and protection frameworks unfold. The complex (geo)politics associated with refugee status adjudication, the heterogeneous legal content of refugee status in different geographical contexts and historical moments, the social diversity of refugee populations, are just few analytical dimensions that are crucially relevant for the identification of who is recognised as a refugee in any given situation, yet unfold beyond and across such institutional configuration. This is especially relevant in the context under examination given the multiple social meanings and affects associated to the term "Afghan refugees in Pakistan", as examined in detail below. It thus seems legitimate to investigate further into the above question.

This is the task undertaken in the following pages, which discuss the processes leading to, and engendered by, the recognition of Afghans in Pakistan as refugees. Attempting to answer the above question in grounded and situated ways, they unravel a variety meanings and practices that are crucial for the correct identification of who should be considered an Afghan refugee in Pakistan, and yet unfold beyond and across the state-centric institutional grid expressed by the legal refugee definition. The discussion wants to bring to the fore the social excesses that unsettle refugee legal scholarship's interpretive frameworks, i.e. the surpluses and residues of meanings, institutions, and practices that are an integral aspect of Afghans' refugee status recognition, but that cannot be fully absorbed or contained by the legal terms of their status. While complicit in defining the content of law associated to Afghans status, these meanings and affects unravel beyond and across such content.

This discussion offers three contributions. First, it wants to clarify the concrete mechanisms and rationales that contextually define who an Afghan refugee in Pakistan is. Second, building upon but moving beyond the state-centred grid reproduced by most refugee legal scholarship, it advances a conceptualisation of refugee status as a productive tension between the content of law and its social excesses. Third, on these bases, it intervenes in debates on the relation between law and disciplinary modalities of power, insisting on a "bottom up" theorisation of law, i.e. one that is firmly grounded in context. Such approach, it is argued, can contribute to a better understanding of the fluid and dispersed ways through which law manifests itself across society and the increasingly complex role assumed by law in modern society.

The argument emerges, in the following pages, out the attempt to answer the research question set out at the beginning of this Introduction. The next section defines the notion of "excess", both conceptually and analytically, opening up the content of the following two substantive sections, which draw from extensive field research material. The first one presents an account of the changing meanings attached to the recognition of Afghans as refugees over the last thirty years, as a way of building upon but moving beyond state-centred understandings of the refugee as an institutional "problem" that can be solved through the correct implementation of legal protection frameworks. It suggests expanding the conceptualisation of refugee status to account for the multi-scalar rationalities and forces in excess of those contained in refugee legal frameworks. The second one deepens the 
argument, and develops a conceptualisation of refugee status as a productive tension: an ordering and disciplining process that can only be captured "from below". The final section offers further elaboration in respect to the aims of the paper.

\section{The excesses of refugee status}

Who is an Afghan refugee in Pakistan? Afghans have a long history of cross-border politically motivated migration. Ever since the establishment of Afghanistan as a buffer state between the British and Russian Empires, the border between the North West Frontier of British India, later Pakistan, and Afghanistan has functioned as an escape route during times of "political persecution" (e.g. Afridi 1980; Edwards 1986; Preece 1985). It was only at the end of the 1970s, following the PDPA coup ${ }^{3}$ and the subsequent occupation of the country by the Soviet Army, that Afghans in Pakistan were recognised as refugees. Since then, more than three million refugees are said to have crossed the Durand Line seeking asylum. The terms of Afghans legal recognition as refugees in Pakistan are unclear, however. The Government of Pakistan (GoP) is not a signatory to the 1951 UN Convention on Refugees and Stateless Persons, nor it has codified in law an asylum regime. Afghans' legal status is elusive-and thus the identification of who amongst them is a refugee remains uncertain. UNHCR recognises Afghans as refugees under its Mandate, but it distinguishes between "old" and "new" caseloads, and there seem to be other discrepancies in the way refugees are "counted" -evidently highlighted by the example presented at the beginning of this paper and discussed in detail below.

Furthermore, each of the dimensions identifying the "Afghan" "refugee caseload" "in Pakistan" is analytically problematic, as it contains and expresses multi-scalar social meanings and affects. First, the political (Rubin 1995) and social (Shahrani, 1987) fragmentation of Afghan society, the local nature of its politics (Glatzer 2007), as much as ethnic (Janata 1990) and religious factionalism (Canfield 1987), in fact, complicate countrywide understandings of Afghans' protection needs. Second, the heterogeneous socioeconomic background of Afghans in Pakistan, the manifold locations of their asylum, as well as their continuing engagement in cross-border activities, render caseload-wide representations of their conditions of asylum equally arduous. Third, the long history of Afghan transnational mobility across the region, the extent of cross-border social ties, and the politically, institutionally and violently contested nature of areas across the AfghanistanPakistan border, complicate even the process of identification of Afghan refugees in Pakistan, as they nuance rigid conceptualisations of the national territory as a linearly bounded unit (Novak, 2011). The multiple meanings and affects attached to the term "Afghan refugees in Pakistan", in other words, render the process of their identification fraught with analytical complications. The following pages are precisely concerned with such meanings and affects, conceiving them as social excesses.

Conceptually, the notion of excess is loosely inspired by Derridian analyses (cf. Derrida 1976, 1992; Clifford 1987; Gasche' 1994), and by the deconstructive imperative they pose. The need to continually interrogate the self-proclaimed closure of discourse by forcing it to account for the excess that always escapes and thus jeopardises this closure (Newman 2001) is in fact a major driver of this study. At its broadest, the latter tries to unmask the "limit of the limit" (ibid) that impedes the closure of the legal category "Afghan refugee in Pakistan". Such analytical perspective is also at the heart of recent political theory contributions that discuss the relation between political subjectivity and law (Samaddar 2007; Balibar 2012),

\footnotetext{
${ }^{3}$ People's Democratic Party of Afghanistan, a faction of Afghan Marxist Party.
} 
and that similarly inspire this study. Working at the intersection of history and politics, these accounts uncover the constitutive meanings that provide the conditions for law's emergence, but that at the same time exceed any given institutional form associated to the state, law and nation (Samaddar 2010). They try to capture the claims associated to, but in excess of, law and the political logic that emerges from law's attempts to absorb and accommodate them (Mezzadra and Neilsen 2012). They foreground the excess of bare over civil life, of exception over rule, of race over nation, of justice over democracy; the social excesses, in other words, that both allow and threaten politics (Mansfield 2011). What follows, thus, attempts to capture the multiple constitutive meanings both contained within, but in excess of, the legal terms of Afghan refugee status, and the latter's "irreducible resistance to synthetic appropriations" (Morgan Wortham 2010: 36).

Analytically, however, the term excess is deployed in the following pages by reference to Golder and Fitzpatrick's (2009) understanding of law as generatively irresolute. Concerned with the role of law in Foucault's scholarship and in turn with the contribution that Foucault can offer to legal scholarship (particularly at international level ${ }^{4}$ ), Golder and Fitzpatrick advance an understanding of law as simultaneously determinate and responsive. Law is determinate, as it must assume a definite content. This is a law "that says no", a "law of prohibition"; the "terminal form" which power takes (Foucault 1982, in ibid: 72). Such "power", however, is always in excess of law itself: it is fluid and mobile; it emerges from a moving substrate of force-relations (Foucault 1978). Law cannot simply exist in a determinate solidity, as it cannot remain tied to any given content. It must engage with what is other to it, with the resistances and transgressions challenging its position. It must assume a labile existence (Golder and Fitzpatrick 2009: 77). Law is thus irresolute, as it is relational: it forms itself in the encounter with what is outside it, to which it is always and dynamically responsive. "This is a law of mutability, a law which is constantly in excess of its determinate self and which is uncontainable in and by its present instantiations" (ibid: 71, my emphasis).

Deploying such conceptualisation of law allows this study, first, to move from a conceptual to an analytical understanding of excess, as the "field of multiple and mobile power relations" in which law operates (Foucault 1978: 98); the outside that provides the conditions for the emergence, existence and transformation of, in this case, Afghan refugee status. Accepting law as generatively irresolute, in fact, means that the identification of who is, who is not, and who should be considered a refugee cannot be exclusively ascertained by reference to the content of law and its correct implementation. Law is neither the truth nor the alibi of power (Foucault, in Golder and Fitzpatrick 2009: 85). Rather, such identification needs to be found in the contextual relation between refugee status and the social field that makes the juridicolegal dimension of asylum possible in the first place. The following two sections, thus, move away from an understanding of refugee law as either 'a service to, or an attempted constrain on' (see Orford 2000) the authorities that sanction who is a refugee. Instead, they examine the processes leading to and engendered by the recognition of Afghans' refugee status, as a way of unravelling the social field which refugee law is in a constant relation with. Foregrounding the complexities of Afghan refugee status adjudication in this manner, they challenge traditional refugee scholarship's state-centred "conceptual grid" and its exclusive concern with the legal contents of protection frameworks. Instead of adjudicating who is or should be considered an Afghan refugee in Pakistan on the basis of national and international legal frameworks, they are concerned with the multi-scalar forces and relations that explain how refugee status comes into being, is maintained and transformed.

${ }^{4}$ See Aalbers and Golder, 2012. 
Second, the above understanding of law allows this study to build upon existing Foucaultian legal scholarship. From this perspective, it conceives Afghans' refugee status as a productive relation. Afghans refugee status is productive in a disciplinary sense, as it produces reality, knowledge and things, in turn establishing domains of objects and rituals of truth (Foucault, 1979; 1980). Applying Foucault's insights on disciplinary power to law itself does not imply law's subordination to such modality of power, or law's "expulsion" from modernity, as suggested by Hunt and Wickham (1994). Rather, it is an attempt to capture the compatibility and contextual relations between the determinate and the responsive dimensions of law (Golder and Fitzpatrick, 2009: 26-28). It is in such relation, this "unresolved movement from determinacy to responsiveness", that "exterity becomes itself formative of law and that law opens itself up to alterity" (Golder and Fitzpatrick 2009: 124-125). Indeed, refugee status is constantly produced, from one moment to the next and in every relation, as it becomes responsive to what is "outside it". If on one side the juridico-legal structure of asylum constitutes and structures the field in which international protection and refugee status unfold, on the other such state-centred inscription is neither static, nor uniform across time and space; it is subject to deflections, manipulations and transgressions; multi-scalar and multidirectional power relations animate its operations. Refugee status expresses a definite legal content, but it is also always in excess of its determinate self; it is a productive relation between the juridico-legal dimension of asylum and its social excesses.

Third, in turn, such understanding of refugee status renders the notion of excess concrete and observable. Indeed, the generative irresolution of refugee status, as it will be argued, can only be captured as it manifests itself in contextual and situated ways. It is through a series of contextual interactions between the juridico-legal and productive dimensions of Afghans status that such status is produced from one moment to the next and in every relation. The following pages find the answer to the question "who is an Afghan refugee in Pakistan?" in the concreteness of refugee status' manifestations. As an ordering and disciplining process that is always rendered incomplete by its excesses, refugee status comes "from below": it is a tension between a state-centred legal content and its multi-scalar excesses.

\section{Afghan status as a problem}

\subsection{Recognition and its excesses}

The beginning of Afghan refugee migration to Pakistan is generally traced to the end of the 1970s, when formal international protection arrangements were set up. Indeed, although Afghans had been seeking sanctuary in Pakistan well before 1978/1979, the years of the PDPA coup and of the Soviet Army occupation of Afghanistan, it was only by the spring of 1979 that "the Government of Pakistan was sufficiently concerned that they asked UNHCR to help" (UNHCR 2004: 4). The arrival of more than 400.000 Afghans between May and November of 1979 prompted the GoP and UNHCR to establish a protection and assistance framework for their asylum (UNHCR 2003).

Both UNHCR and the GoP recognised Afghans as refugees on a prima facie basis. UNHCR operated on the basis of its Mandate: prima facie recognition is usually applied in situations of large-scale influx of asylum seekers, where any attempt at individual refugee status determination is too lengthy and/or impractical. Through such recognition, status is granted collectively to a group of persons, on the basis of 'readily apparent, objective circumstances in the country of origin giving rise to exodus. Its purpose is to ensure admission to safety, protection from refoulement and basic humanitarian treatment to those patently in need of it' (Rutinwa 2002: 1). The GoP, however, is not a signatory of the above mentioned 1951 Convention, and its associated 1967 Protocol. 'With respect to states who are not parties to 
relevant refugee law instruments, it seems that the question of refugee definition is circumvented in practice [...] the definition to which logically reference should be made is rarely formulated: it seems to be the suppressed, tacitly held, premise of the syllogistic reasoning involved' (Zieck 2008: 255). Indeed, although Gen. Zia, then president of Pakistan, "announced" refuge for Afghans, the government failed to codify in law such recognition: the definition used was not disclosed and no law has ever provided criteria for identifying who should be considered an Afghan refugee.

To be sure, administrative and other governmental documents do refer to Afghans as refugees. Most notably, the Handbook for Refugee Management in Pakistan of 1984 (see Centlivres 1993) describes Afghans as 'refugees on humanitarian grounds', and makes reference to Humanitarian Law, as well as to religious and tribal norms. This is confirmed by the first GoP's Chief Commissioner for Afghan Refugees in the following terms:

Apart from the Geneva Convention and other internationally recognized humanitarian practices, which is [sic] relatively speaking only a recent postSecond World War phenomenon, Pakistan's humanitarian gesture is influenced by various quranic injunctions on the treatment of migrants who forsake their homes in the cause of Allah (Azhar 1990: 108-109).

UNHCR Pakistan phrases such ambiguous recognition in the following manner

Although the Government of Pakistan has never signed the 1951 Convention on refugees, it honoured its spirit and hosted millions of Afghans who fled the wars in their homeland. It was helping refugees in the months before UNHCR opened its first offices late in 1979 and even today the Government of Pakistan is explicitly committed to the principle of voluntary repatriation (UNHCR 2004: 11).

A series of Agreements and Memorandums of Understanding signed by the GoP since 1988 (Zieck 2008; GoP/GoA/UNHCR 2003) as well as official letters between various Ministries under whose jurisdiction Afghans fall, similarly make reference to the category "Afghan refugees". For example SAFRON (the Kashmir Affairs \& Northern Areas and Frontier Regions Division of the GoP), in a circular letter dated 25 July 1997 to the Ministry of Interior asserts

During the temporary stay of the Afghan Refugees in Pakistan all laws applicable to the local citizens shall apply to the Afghan Refugees. However, as the Government has provided refuge to the Afghan refugees on humanitarian grounds, the provisions of the Foreigner's Act and other such rules pertaining to foreigners residing in Pakistan do not apply to the Afghan Refugees (in Kansi 2003; see also Marwat 2004)

Other such documents and GoP's circulars exist (ibid: 52). Gen. Zia "announced refuge" and that was the rule, but the absence of any legal codification makes Afghans' status elusive. Who is an Afghan refugee?

The long held belief that 'the purpose of any definition or description of the class of refugees is to facilitate, and justify, aid and protection' (Goodwin Gill 1996: 12) has contributed to the reproduction, across different strands of refugee legal scholarship, of a state-centric approach that focuses on the sources of national law and international legal frameworks. Most notably, positivist (e.g. ibid; Hathaway 1997) and human rights (e.g. Weissbrodt and Newman 1990) approaches (respectively the most influential and the currently dominant perspectives in the field, see Lambert 2008) view refugee law as a set of obligations between states, or of states under human rights law (Goodwin-Gill 2004). Similarly, institutionalist approaches, although 
moving beyond the strictly inter-state legislative realm to foreground the networked activities of transnational actors (see Lambert 2008: 349-352; Goldstein et al. 2001), ultimately emphasise the role that such networks command in imposing international legal constraints on governments. The same goes for so-called participatory approaches, which are aimed at including refugees themselves for accountability purposes (Turk and Eister 2010), and for keeping in check relevant authorities. Even political economy approaches to refugee law, which see refugee migration and protection as a confirmation of the unequal structures associated with the world economy, ultimately see refugee protection as a ruse to cover Western powers geopolitical interests (Chimni 1998), a fig leaf for powerful countries such as the US to continue its imperial rule (Chandler 2006).

However, approaching the above question from the perspective of the state-centred "conceptual grid" expressed by the refugee definition, as these different strands of scholarship do, disregards several analytical dimensions explaining and providing the conditions for Afghan refugee status recognition. As the provisions contained in the GoP's announcement and related documents suggest, in fact, the terms that "facilitate and justify aid and protection" are, in this case, only partially contained within the institutional categories defined by refugee protection's legal frameworks. Surely, those migrants coming from across the Durand Line did lack state protection and did deserve, from a Convention perspective, the recognition of their status as refugees. Yet by considering "Afghans as brethren in faith", refugee status was also premised on religious injunctions on the treatment of migrants. Furthermore, Afghans were recognised as a tribal "entity", and allowed to maintain their own social governance institutions (Azhar 1986: 2; 1990). The ambiguous recognition of Afghans status, in other words, was the result of the intersection of humanitarian, religious and tribal norms; harnessing these forces, the GoP recognised Afghans as refugees, albeit in ways that exceed the parameters of international refugee law frameworks. It attributed contents to refugee status that are in excess of the content of law, and that need to be analytically accounted for.

The refugee is not a "given" which generates problems that must be resolved, but rather a "question" whose formation and obviousness must itself be subject to analysis (Rabinow and Rose 2003: 8). Questioning, rather than taking for granted, the logics and operational mechanisms that define who a refugee is, does not mean disregarding the content of law. On the contrary, it involves assessing how different solutions to a problem are constructed and how they result from a specific form of problematisation (Foucault PPP; Foucault in Rabinow and Rose 2003: xviii). From this analytical perspective, the above scholarship's concern with the legal content of refugee status needs to be expanded to capture the ensemble of legal and extra-legal rationalities and forces that identify "Afghan refugees in Pakistan" as a distinct and distinguishable object of international protection. Indeed, approaching the refugee "problem" as a question foregrounds the multi-scalar social forces that explain such recognition, and the role that law plays in harnessing and ordering them. The point can also be developed in relation to the "correct" implementation of refugee protection obligations put forward by the above scholarship, as described next.

\subsection{Protection and its limits}

Despite its ambiguities, Afghans status did produce a definite content. The legal and extralegal rationalities defining and distinguishing them as persons in need of international protection simultaneously set clear limits to protection activities. By defining refuge "purely as a temporary measure, with no provision for long term integration or assimilation in the socio-economic fibre of the country" (Azhar 1986: 3), the announcement also set clear boundaries to the type of protection arrangements that Afghans were entitled to. In particular, 
it limited the scope of UNHCR's Mandate, leaving voluntary repatriation as the only durable solutions pursuable ${ }^{5}$. After the initial emergency phase, it constrained the scope of assistance activities to those geared towards self-reliance, as opposed to others that may have facilitated Afghans integration. The absence of legal codification, allowed the GoP to withdraw or selectively apply such recognition independently from the opinion of those agencies, or the actual protection needs of Afghans. Indeed, while during the initial decade of asylum such elusiveness did not constitute an impediment to Afghans' effective (legal) protection, in subsequent years, and in parallel to the evolving situation in Afghanistan and the rapidly changing geopolitical context, the limits of such protection arrangements were brought to the fore.

With the withdrawal of the Soviet Union from Afghanistan, the GoP's attitude towards Afghans progressively worsened. Already in 1993 the GoP indicated that it would no longer accept new arrivals as prima facie refugees (Macleod 2001: 44) and it stopped registering or issuing refugee documentation from 1995. After 1998, all Afghans arriving in Pakistan were to be considered economic migrants by the GoP (UNHCR 2004c: 69). The absence of an effective implementation of such policy change, however, meant that UNHCR judged the 'protection climate as broadly acceptable, even if not underpinned by any legally defined asylum framework' (Macleod 2001: 45). It was only after 2000, when the GoP began to consistently apply the changed policy, that such "climate" took a dramatic turn for the worse. In 2001, SAFRON officially redefined its position, in another circular letter to the Ministry of Interior:

Henceforth, all those Afghans who do not possess "refugee cards"/"refugee permit" issued by UNHCR/Commissionerate for Afghan Refugees, or who have not been granted visas on their passports, shall be considered illegal immigrants and will be treated as per Foreigner's Act and laws applicable to foreigners (in Kansi 2003)

As a way of asserting the boundaries of the re-defined meaning of Afghans' recognition, the GoP pre-empted, in some cases, Afghans' right to seek asylum by attempting to close the border. According to reports, in February 2002 several thousand of them fleeing human rights abuses in northern Afghanistan were denied access to Pakistan and the possibility to be registered with UNHCR (Bialczyk 2008). Those Afghans who did manage to cross the border fleeing the consequences of Operation Enduring Freedom's military campaign were hosted in fenced refugee villages adjacent to the border itself. Unlike their compatriots, their movement was restricted and they were entirely dependent on food distributions and other provisions for their survival. These new arrivals were defined by UNHCR as the "new caseload", but their status and recognition were possibly even more ambiguous than those of the "old caseload". In the words of the Country Representative of an International NGO operating in the newly opened camps:

Despite calling them refugees, Afghans in new camps were technically treated by UNHCR as asylum seekers. The problem, as you know, is that the GoP never formalised the status of Afghans and their status have been under negotiation between UNHCR and the GoP for a long time. In any case, the GoP categorised Afghans arriving in 2002 as Externally Displaced Persons a category which does not exist in refugee law (personal email communication).

\footnotetext{
5 "A durable solution for refugees is one that ends the cycle of displacement by resolving their plight so that they can live normal lives. Traditionally, one of three durable solutions are pursued" voluntary repatriation, local integration or resettlement to a third country. (UNHCR 2005a: 137).
} 
Furthermore, the erosion of protection standards was de facto extended to the "old caseload". Deportations, consistent pressure and harassment of Afghans in bazaars and urban areas (WFP, unp.), the progressive worsening of security in some camps (HCRP 2009), as much as the forcible closure of some of them, have all contributed to a situation were very low protection standards, as much as documented cases of human rights violations (HRW 2002), have become the norm. The situation is further compounded by the widespread absence of legal documentation, as most refugees were never provided with tangible proof of their status (Zieck 2008), leaving Afghans subject to the whim of authorities.

In parallel to this situation, both academics and policy-makers have attempted to improve protection standards through advocacy and scholarly work. As above, however, although heterogeneous in their concerns all these studies insist on the content of law and its "correct" implementation by relevant authorities. UNHCR's Legal Protection Section in Geneva, for example, funded a series of workshops on Afghans need of protection, and the legal obligations of the GoP in this respect. The workshops were organised by SHARP, a Pakistani human rights organisation; they were meant to raise awareness about the plight of Afghans and to establish, in light of international and humanitarian conventions as well as existing national laws, the GoP's legal obligations towards Afghans' protection (SHARP 2002a; 2003). based on the evaluation of a number of Agreements Pakistan concluded with UNHCR and with Afghanistan, Zieck's (2008) comprehensive study similarly insists on the binding nature of the GoP's and UNHCR's prima facie recognition of the "old caseload". Concerned with non-repatriating Afghans, she makes the legal argument that those who have been recognised as refugees on a prima facie basis are entitled to retain that status until cessation is warranted. Human rights organisations have reminded the GoP that the obligation of non refoulement is now a generally accepted and binding principle of customary international law (HRW 2001; Lauterpacht and Bethlehem 2003). They have underlined how the Constitution of Pakistan guarantees the right to enjoy the protection of law and to be treated in accordance with law to every person within Pakistan (AI 2004). They have also reminded the "international community" that it is its duty to cooperate in the protection to those that do not wish to return (AI 2002; Malik 2005), as asserted in The Preamble of the UN Refugee Convention and numerous ExCom Conclusions (HRW 2002: 15).

While disparate in its rationalities and concerns, such scholarly and advocacy work attempts to uphold protection standards by putting pressure on the GoP, UNHCR, and the "international community". Once again, if the refugee "problem" is taken as a given and defined exclusively in terms of "lack of state protection", solutions to such "problem" can only be found by appealing to the rights and obligations of states under relevant refugee legislation. Indeed, this scholarship's value stems precisely from its oppositional engagement with the authorities that set limits to Afghans protection, in a situation of clear humanitarian abuses. Such self-referential circularity, however, prevents scholars from thinking anew about the relationship between power, the state, sovereignty and international law (Orford 2000). Indeed, according to such scholarship

The principal disciplinary question relating to power is how to orient international law to power, or how best to deal with the realities of the operations of power in the international sphere. As a result, international lawyers focus most of their attention on analysing the ways in which international law can assist in constraining, disabling or negotiating with those who are imagined as holding power (ibid).

Put differently, the conceptualisation of power deployed by these approaches seems problematic. This is so, particularly, in regards to the positivist tradition, and its 
understanding of refugee law as 'an abstract system of rules which can be identified, objectively interpreted, and enforced' (cf. Chimni 1998: 352). Such understanding limits the possibility of engagement with the politics of refugee status adjudication as it fails to capture the 'complexities of the process of law formation' (Lambert 2008: 353), and its selective implementation (Chimni 2000). Even those approaches that emphasise the politics associated with refugee protection deploy a similar conceptualisation of power as something that can be possessed, whether by states and its dominant classes, as in political economy approaches, or by transnational networks of governance (cf. Novak 2011). As above, it seems that insisting on the content of law and its "correct" implementation, does not address the extra-legal multiscalar forces and relations that allow refugee status' limits to be drawn and re-written; they don't address its excesses. On the contrary, what follows is precisely concerned with the relation between refugee status' limits and excesses.

\section{Afghan status as a tension}

\subsection{Productive refugee status}

The previous section has suggested that the identification of who is a refugee cannot be established exclusively by reference to the legal content of national and international protection frameworks, as this fails to capture the variously scaled extra-legal forces that explain how refugee status recognition comes into being, is maintained or transformed. The point can be deepened and rendered more systematic by direct reference to Foucaultian legal scholarship and the distinction between repressive and productive dimensions of law.

Refugee status possesses a repressive dimension, where clear limits identifying those who are to be considered refugees in the first place, are drawn. As exemplified by Gen. Zia's announcement of refuge, law "speaks and that is the rule. The pure form of power resides in the function of the legislator; and its mode of action [...] is of a juridico-discursive character" (Foucault 1978: 83). The recognition of Afghans status by the GoP, and its subsequent withdrawal, evidences the repressive nature of refugee law, which includes/excludes, classifies and prevents, which "patrols the boundaries" of its object of intervention (cf. Hörnqvist 2010: 11-13). This dimension is the main concern of the above scholarship, which insists on the content of law in its attempt to identify who an Afghan refugee is or should be considered such. At the same time, however, refugee status also operates in productive terms. It is productive in a "disciplinary" sense, as it produces reality, knowledge and things, in turn establishing domains of objects and rituals of truth (Foucault 1979; 1980). Afghan refugee status enabled protection mechanisms and facilitated the circulation of legal knowledge, of humanitarian discourses and practices, of tribal and religious institutions. It opened up opportunities for co-operative conduct, as much as for oppositional challenges to the limits it set around them, such as those presented above. It demarcated a discursive field within which these institutions and practices could unfold. This does not imply the subordination of law to disciplinary modalities of power (cf. Foucault 1979: 194 and 217; Golder and Fitzpatrick 2009: 27-35, and Concluding Remarks). On the contrary, it sets refugee status' legal content against the field of multiple and mobile power relations that are harnessed by it, and through which it operates. Refugee status is a productive relation between law and its excesses.

First, Afghan refugee status was constitutively in excess of its legal determination. Undeniably, status recognition produced a definite legal content: it singled out Afghans as refugees on a "humanitarian basis" and activated protection functions; it facilitated UNHCR's Mandate recognition and allowed its operations; it sanctioned its (changing) meanings and effects in Handbooks, documents and Memos that, however ambiguously, still provide legal 
bases for the advocacy work discussed above. The identification of "Afghan refugees in Pakistan" as persons in need of international protection transformed them into a definite, however contested, object of legal concern and intervention. Yet, Afghan status recognition simultaneously appealed to, and was constituted by, humanitarian, religious, and tribal norms, discourses and forces, that were in excess of those contained in existing legal frameworks. In producing a definite legal object, Afghans' status recognition also, simultaneously, produced contents in excess of its legal determination, entering into a productive relation with them.

Second, in fact, such constitutive ambiguity reverberated across the complex 'ensemble formed by institutions, procedures, analyses, and reflections, calculations and tactics' (Foucault 1991: 102), which were engendered by the legal object "Afghan refugees". Protection arrangements reflected both law and its excesses. As the sovereign authority offering protection to Afghans, the GoP gave SAFRON overall administrative jurisdiction over refugees; it was assisted by the Chief Commissionerate for Afghan Refugees (CAR), operating at Federal level and overseeing the work of Provincial CARs (CAR 1982). Provincial governments maintained administrative jurisdiction over places where refugees reside, though they delegated functions to Refugee Commissioners. "Down below there are District Administrators for overall coordination. At the sharp end there are Refugee Village Administrators who physically carry out the administration of refugee camps" (ibid). The humanitarian principles invoked, additionally, enabled UNHCR, various UN agencies and large International NGOs to begin operations. Over the years the number of non-state humanitarian organisations, as well as their relevance in defining the "correct" conduct of protection activities, increased exponentially. Furthermore, as recognised "tribal entities", Afghans were allowed to maintain their kin-based governance institutions, which were in excess of those set up by the GoP and UNHCR described above (see also food distributions below). In other words, much like the object of concern enabling their activities, Afghans protection arrangements were the expression of all the legal and extra-legal rationalities and forces harnessed by, but in excess of, their status as refugees.

Mirroring the previous section, third, this relation can also be captured by looking at the limits defined by refugee status recognition. In addition to the above arrangements, in fact, Afghans protection needs engendered further preoccupations: how to count refugees (registration procedures), where to host them (establishment of camps), how to identify them (documentation), how to cater for their needs (food distributions, education or health provisions, etc.), how to solve disputes (conflict-resolution mechanisms). These required experts, consultants or academics to devise best practices, to assess projects and to monitor procedures. On one side, Afghans status enabled "diverse types of actors, agents, or identities to arise from and to inform" protection activities (cf. Xavier Inda 2005: 10). On the other side, the ambiguous and changing limits of their possible interventions meant that their activities were regulated, controlled, and stirred towards specific ends (Dean 1999; Lemke 2001). In excess of its legal content, the limits drawn around Afghans' protection needs enabled but contradictorily shaped the conduct of those involved (cf. Hardy 2003); they created the competence to act in a certain way (cf. Hörnqvist 2010: 11-13). Refugee status acts as "policy"; a regulation concerned with order and the disposition of things (Constable 1993). This is clearly not a unidirectional process, but rather a dynamic and contextual relation between the content of law and its excesses. Refugee status opened up spaces for cooperative and compliant conduct, but it also created the conditions for oppositional challenges, such as those of the advocacy work above; and for transgressions and manipulations, such as those described below in relation to food distributions.

Indeed, fourth, the conceptualisation of refugee status as a productive relation means that, the identification of who is an Afghan refugee in Pakistan and who is not can only be answered 
by reference to the ordered but deeply contextual settings of these relations. As discussed in what follows, refugee status is not possessed, but is rather produced from one moment to the next, and in every relation. Rendered incomplete by its excesses, refugee status "comes from below": it is a tension between a legal content and its excesses.

\subsection{Refugee status from below}

Classically associated with refugee assistance, food distributions also serve protection functions: they are an important component of protection activities, geared towards the provision of adequate nutrition to beneficiaries' populations. They confirm the definite legal content of Afghans status: it is only by singling them out as beneficiaries of international protection that such distributions could take place. At the same time, they confirm the productive relation between such content and its excesses. Indeed, as discussed here, food distributions are a prime example of the contextual and dynamic character of such relation.

This is so, first, in relation to the content produced. As a consequence of status recognition, all Afghans were entitled to food rations. However, only those who registered in camps and became members of one of seven Islamic political parties approved by the GoP, could access them (CAR 1982). Over three hundred camps were set up on land owned by the government, or rented from local landowners (Boesen 1985). Each camp had an Administrator and groups of five camps were put under the jurisdiction of Area Administrators, which in turn were headed by a District/Agency Administrator, who was reporting to the CAR (CAR 1982). The overwhelming majority was set up in so-called tribal areas adjacent to the border, where the majority of Afghans sought refuge because of their kin-based cross-border links. The semiautonomous nature of these areas implies that humanitarian activities need to be negotiated with tribal authorities, as opposed or in addition to local government officials and Political Agents, and entangles them in local feuds (Christensen 1984). In some cases, Afghans were given land to live on for free by local landowners in a spirit of Islamic and kin solidarity (AREU 2006a: 14), yet subjecting them to 'the duties hospitality implies' (Centlivres et al. 1988: 147). In other cases, the above-described administrative structure was subverted as camps were effectively run by jihadi commanders (AREU 2006a: 14). The legal content expressed by Afghans' status was thus re-defined contextually, by kin-based and Cold Warrelated excesses.

Second, as above, such constitutive ambiguity was reflected in arrangements organised for their delivery. All imported food was distributed by the National Logistic Cell to provincial and district warehouses, and at times directly to some camps (WFP/UNHCR 1992). Wheat was handled by the Ministry of Food and Agriculture and merged with national stocks; other items were handled by CAR, which was in charge of distributions within the camp (ibid.). Though impressive in its effectiveness vis-à-vis logistics and number of beneficiaries reached, "losses" and pipeline breakdowns were recorded by Christensen (1984: 17-27) throughout the chain, some of which related to contingencies such as strikes or market availability of goods. Others excesses, however, shaped effective quantities of food received by refugees. Reflecting the kin-based rationalities behind Afghans' status recognition, in some camps food items were distributed through the figure of the ration malik, "traditional leaders" in charge of dealing with the camp administration, handling the requisite paperwork, transporting supplies to their section of the camp and distributing rations to household heads (Edwards 1986; Centlivres 1993). Though they efficiently dealt with such task, they also subjected distributions to inter-clan feuds and would not distribute items at their whim (Novak 2007). Indeed, kin-based "codes of conduct" marginalised minority ethnic groups within camps (Janata 1990), as well as, intersecting with patriarchy (Boesen 1985) and the socio-economic status of each refugee (Farr 1990), some women and the most dispossessed. 
Partly for these reasons, but also due to the consolidation and expansion of relief efforts, to Mujaheddin parties' gradual increase in strength within the camps, and to the enlargement of the GoP administrative camp structure (Christensen 1984), the system was changed, with refugee household heads obtaining rations from the camp administration on presentation of their family ration cards. This was not the case in Balochistan where tribal leaders' relative power allowed them to continue their functions vis-à-vis food distributions (WFP/UNHCR 1994). Much like above, in other words, arrangements for food distributions reflected and reproduced all rationalities and forces expressed by, but in excess of, Afghans' legal status. Indeed, they were the contextual result of the productive tension between them all.

Third, the contextually re-defined legal content enabling food distributions was rendered even more contingent by the numerous manipulations, transgressions and re-appropriations to which they were subjected. The actual number of those receiving food -i.e. who actually is an Afghan refugee in Pakistan, for the purposes of food distribution-, was the dynamic result of multi-scalar and multi-directional tensions. At times, this was "simply" due to embezzlement. Benazir Bhutto stated that the number of registered refugees was, from the very beginning, inflated in order to obtain more international aid (USCR 1982), something seemingly confirmed by a 1984 survey (Sardie 1984) suggesting that over a third of refugees were 'missing', because they had returned, double registered or engaged in nomadic wanderings. Other transgressions however, can be traced to the Cold War logic, which enabled food distributions to 'bachelors camps' populated exclusively by male armed combatants; this is something certainly problematic vis-à-vis the legal content of Afghans status, given the need to "maintain the civilian and humanitarian character of asylum (UNHCR 2004d). Indeed, across all camps, until 1989 some refugees had 'periodically been going back to fight jihad' (BAAG 1987: 32), contributing to these transgressions themselves. In other cases, food distribution mechanisms were re-appropriated for ends that, although not as contradictorily as the ones just mentioned, were nevertheless in excess of the protection needs enabling food deliveries in the first place. Refugees themselves were not passive recipients of food: even leaving aside the role of maliks, Christensen (1984) indicates how some distributed items were sold in bazaars, with cash income facilitating the acquisition of other staples, and Farmat (1990) suggests that a 'secondary market' for ration passbooks existed. A more recent report (WFP/UNHCR 2003: 11) also suggests that, once food delivery is completed, CAR officials collect empty food containers and sell them through auction, sale proceeds reportedly being used to pay salaries of support staff in the camps (see also below NGOs).

As evidence of the hierarchical and structured nature of these relations, epochal changes dramatically reconfigured the productive relation that sustained food distributions during this period. The full implications of these changes can be only sketched here, as a way of reinforcing the point. After the excesses of the Cold War and in line with geopolitical restructuring processes of the time, for example, major donors' dramatically reduced funding for protection operations, which dramatically started to dwindle. Following the Geneva Accords and the withdrawal of the Soviet Union from Afghanistan, the humanitarian industry's attention focused on the rehabilitation of Afghanistan as a pull factor for the expected mass repatriation, and the GoP was keen to promote repatriation. From 1994 the socalled "old caseload" (i.e. those refugees who arrived as a consequence of the Soviet occupation) entered a Care \& Maintenance phase. Once again, the content associated with Afghans status was re-defined. In 1995, the World Food Program (WFP) closed its general food distributions programme, on the basis of perceived changes in refugee needs (WFP/UNHCR 1992): distributions of food items were restricted to cover only the "vulnerable cases" amongst registered Afghans, even if all Afghans, until then, were still considered prima facie refugees. Indeed, food distributions had to accommodate the new 
limits set by the above-mentioned vigorous repatriation drive. It became an instrument of its disciplinary logic: food items, together with cash, were distributed to those registering for voluntary repatriation. The large number of Afghans (and indeed Pakistanis) obtaining such repatriation grants without being entitled to them, i.e. the numerous transgressions to such logic, prompted UNHCR and the GoP, in turn, to change procedures and to introduce iris scanning machines at repatriation centres.

Operation Enduring Freedom and the military operations associated with the fall of the Taleban regime similarly prompted further transformations. For the purposes of this discussion, suffice to say that, while protection standards progressively diminished for most Afghans, some new arrivals were hosted in fenced refugee camps, and did receive food. They constituted a "new caseload" which, as discussed above, had an even more ambiguous legal content than the "old" one. For them distributions were organised by NGOs, whose numbers had multiplied during the 1990s as a consequence of funding cuts and the re-definition of policies that took place in those years. Confirming such ambiguous content with their operations, they also produced their own excesses, as they distributed food on the basis of their own best practices and disciplinary rationalities (see for example WFP/UNHCR/Intersos 2003: 2), adding further layers of negotiations, transgressions and re-appropriations.

\section{Concluding Remarks}

Much of what has just been discussed may seem alien to traditional approaches to the refugee question, and their understanding of refugee status exclusively in relation to its legal content. Who is a refugee and who isn't, from the latter's perspective, should be ascertained by reference to existing agreements and the sources of refugee law more in general (e.g. Zieck 2008). The previous discussion, instead, moved beyond an exclusive concern with the "repressive" dimensions of refugee status adjudication, setting it in relation to its excesses to the multi-scalar field of power relations, which nurtures the conditions for refugee status emergence, transformations and effects (cf. Foucault 1978: 98). It challenged, at the outset, traditional approaches to the refugee "problem" and their exclusive concern with legal contents. It highlighted instead the excesses behind the recognition of Afghan refugee status, as well as the limits attached to such recognition, and how they were both reflected and reproduced in Afghans protection arrangements. This was not to disregard, or question, the overriding relevance of refugee status adjudication. Deepening the argument, it postulated that refugee status operates both in repressive and productive terms; the former dimension sets (legal) limits and patrols (legal) boundaries; the latter harnesses, orders and attempts to discipline multiple forces, setting them in relation to each other. Further still, it conceived of that relation as a structured, but contextual and contingent, productive tension, that can only be captured "from below". On these bases, it is possible to project further remarks.

One of the aims of this paper is to highlight the contributions that the conceptualisation of refugee status as a productive relation can offer to traditional refugee legal scholarship. Three are highlighted in particular. First, such analytics suggests re-considering the categories and concepts expressed by national and international frameworks. This does not mean disregarding their legal value, but rather setting them in relation to, in this case, the humanitarian, religious and kin-based rationalities and forces explaining Afghans recognition. Insisting on the content of law disregards these extra-legal rationalities and forces. Put differently, this analytics prompts scholars to recognise the relevance of non-state centred conceptualisations of political community, asylum and social order, as an integral part of the process of law formation and of its interpretation and implementation. This seems absolutely crucial in contexts where the meaning of "sovereignty" or "protection" can only be unfolded 
in historically specific and contextual ways (though perhaps for this reason, in all contexts), but also, for instance, in relation to forms of transnational migration where such rationalities and forces play an enormous role. Indeed, second, the above analytics suggests thinking about those categories and concepts in productive terms, even during oppositional engagements with the repressive dimensions of law. The contextual and contingent significance of refugee status as much as its transgressions and re-appropriations can only be captured by enlarging the analytical context to the productive relations engendered by law. Such analytical enlargement may favour a better explanation of the limits imposed to international protection in contexts such as the one discussed here, and thus a better conceptualisation of appropriate solutions and policy responses. Third and following from this, the productive dimensions of legal status presented here suggest thinking anew about the relation between law and power. The idea that law is at the service of, or constrains, relevant authorities is in fact put into question by law's reverberations across non-legal dimensions, and law's imbrications with multiple forms of power. By appreciating the ability of law to operate through juridical and disciplinary mechanisms, the above analytics captures both the fluid and dispersed ways through which power manifests itself across society and the increasingly complex role assumed by law in modern society (cf. Munro 2001: 557).

The relation between law and discipline has also gripped legal literature on Foucault and this warrants an intervention. Hunt and Wickham (1994) interpret Foucault's concern with disciplinary modes of power (e.g. Foucault 1979), as historical evidence of law's decreased importance as mean and expression of power. Their reading of Foucault rejects a negative or repressive view of the power of law, and focuses instead on the dispersed disciplinary mechanisms linking objects and truth, truth and knowledge (Hunt and Wickham 1994: 1216). They, and like them several others, expel law from modernity (Golder and Fitzpatrick 2009: 12-25). The above analysis suggests, on the contrary, that the repressive dimension of law both constitutes the disciplined object, and structures its functioning. Not only is law compatible with disciplinary modalities of power, but it is always in a relation with what is "outside it" (ibid). Indeed, as the above analysis suggests, the repressive dimension of refugee status reproduces itself through its relations with the multi-scalar field of force-relations in which it unfolds. Two further points can be thus made in this respect.

First, law's multi-scalar reverberations can only be captured from 'below'. It is only by setting such conceptualisation in context that the multiple forces structuring, albeit contextually and contingently, the relation between law and its excesses come preponderantly to the fore. The multi-scalar and hierarchically ordered protection machinery engendered by refugee law can only be fully captured by contextual and situated studies. Following from this, second, the above study also suggests that refugee status constitutes, supports, transforms, and strengthens the multi-scalar field of power relations that give raise to and is reproduced by it -as much as its hierarchies. Indeed, the above analysis seems to suggest that powerful states, international organisations, state- and non-state centred elites, legal and shadow networks, etc., are able to maintain their dominant positions by operating through both refugee status' legal content and its excesses. Refugee status provides the conditions for the reproduction of unequal distributions of power.

The lack of concern for the sources of power that are external to law itself is perhaps a limitation of some Foucaultian analyses (though see Hornqvist 2010, on the relation between productive power and the wider economic forces shaping society; or Hunt 2004, on Foucault and Marx), which clearly needs to be addressed. Yet, their emphasis on the role that law plays in the articulation and reproduction of hegemonic dominations (Foucault 1978: 94) -both conceptually by insisting on the content of existing legal frameworks, and contextually by 
providing an institutional setting for their material reproduction- forcefully questions narrow conceptions of refugee law as something analytically separate from its excesses.

\section{REFERENCES}

Aalbers T. and Golder B. (eds), 'International Legal Theory: Symposium on Foucault' (2012) Leiden Journal of International Law 25(3) 603

Afridi O.K., Mahsud Monograph (Peshawar: Tribal Affairs Research Cell, Home and Tribal Affairs Department, Government of NWFP, 1980)

Agamben, G., We Refugees (1995). Symposium 49 (2) 114

AI -Amnesty International, Pakistan: human rights abuses in the search for al-Qa'ida and Taleban in the tribal areas. (2004) Report available at repository.forcedmigration.org/show_metadata.jsp?pid=fmo:4230 accessed 26 December 2011

AI -Amnesty International, Afghanistan: Continuing need for protection and standards for return of Afghan refugees (2002) Report available at www.amnesty.org/en/library/info/ASA11/014/2002/en accessed 26 December 2011

Anker D., 'Refugee Law, Gender and the Human Rights Paradigm' (2002) Harvard Human Rights Journal 15, 133

Azhar, S. Paper on the Refugee Situation in Pakistan given to the RSP Seminar on the Implementation of the OAU/UN Convention of Refugees (1986) Available at: repository.forcedmigration.org/pdf/?pid=fmo:271 accessed 16 June 2010

Azhar S., 'Afghan Refugees in Pakistan: the Pakistani View' in E.W. Anderson and N. Hatch Dupree, eds., The Cultural Basis of Afghan Nationalism. (London: Pinter, 1990) 105-114.

Balibar E. Justice and Equality: A Political Dilemma? Pascal, Plato, Marx in E. Balibar S. Mezzadra R. Samaddar (eds) The Borders of Justice. (Philadelphia: Temple University Press, 2012) 9-32.

Bialczyk, A, Voluntary repatriation' and the case of Afghanistan: a critical examination. (Oxford: Refugee Studies Centre 2008).

CAR, Relief Work for Afghan Refugees (Peshawar: Commissionerate for Afghan Refugees, 1982).

CAR, Humanitarian Assistance Program for Afghan Refugees (Peshawar: Commissionerate for Afghan Refugees, 1994)

Centlivres P. and Centlivres-Demont, M. 'Afghan Refugees in Pakistan: an Ambiguous Identity' (1988) Journal of Refugee Studies 1(2) 141

Centlivres P. A State of the Art Review of Research of Internally Displaced, Refugees and Returnees from and in Afghanistan Report prepared for the Planning Committee of the Fourth International Research and Advisory Panel Conference on Forced Migration (London: IRAP 1993).

Chandler D, Empire in Denial: The Politics of State-building (London: Pluto Press, 2006)

Chimni, B.S., The Geopolitics of Refugee Studies: A View from the South (1998) Journal of Refugee Studies 11(4), 350 
Chimni, B.S. Globalisation, Humanitarianism and the Erosion of Refugee Protection (2000) Journal of Refugee Studies 13(3), 243

Christensen, H. Afghan Refugees in Pakistan: from Emergency towards Self-reliance. Report on the Food Relief Situation and Related Socio-Economic Aspects (Geneva: UNRISD, 1984).

Clifford M.R., 'Crossing (out) the Boundary: Foucault and Derrida on transgressing Transgression' (1987) Philosophy Today 31: 223

Crisp J, "Who has counted the refugees?" UNHCR and the politics of numbers (New Issues in Refugee Research, Working Paper No. 12. Geneva: UNHCR, 1999)

DACAAR, IRC, MADERA (Danish Committee for Aid to Afghan Refugees / International Rescue Committee / Mission d'Aide au Développement des Economies Rurales en Afghanistan) "Expected Repatriation Patterns 2002. Results of Survey in Refugee Camps in NWFP 18 February - 22 march 2002". (2002) Available at www.dacaar.org/upload/Source/PDf/dacaarsurvey.pdf Accessed 26/11/2005

Derrida J., trans. Gayatri Chakravorty Spivak. Of Grammatology (Baltimore, MD: Johns Hopkins University Press, 1976).

Derrida J. "Force of Law: The Mystical Foundation of Authority", in Drucilla Cornell et al. (eds.) Deconstruction \& the Possibility of Justice (New York: Routledge 1992), 3-66.

Newman S. "Derrida's Deconstruction Of Authority" (2001) Philosophy \& Social Criticism, 27(3), 1

Edwards, D.B. Marginality and Migration: Cultural Dimensions of the Afghan Refugee Problem. (1986) International Migration Review Special Issue: Refugees Issues and Direction 20(2), 313

Foucault M. The History of Sexuality. Vol. 1 An Introduction. (London: Penguin, 1978)

Foucault M. Discipline and Punish: the birth of the prison translated from the French by Alan Sheridan. (Harmondsworth: Penguin, 1979)

Foucault M. Power/Knowledge: Selected Interviews and Other Writings, 1972-1977. Ed. Colin Gordon, translated by Colin Gordon et al. (New York: Pantheo 1980)

Foucault, M. 'Governmentality' in G. Burchell, C. Gordon, and P. Miller (eds) The Foucault Effect: Studies in Governmentality. (Toronto: Harvester Wheatsheaf, 1991)

Gasché R. Inventions of Difference: On Jacques Derrida (Cambridge: Harvard UP, 1994)

Glatzer B. "War and boundaries in Afghanistan: significance and relativity of local social boundaries" Weld des Islams (2001) 42(3): 379

Golder B. and Fitzpatrick T. Foucault's Law. (Abingdon: Routledge, 2009)

Goldstein J.L., Kahler M., Keohane R. and Slaughter A. Legalization and World Politics (Chicago: MIT Press, 2001)

Goodwill-Gill G. The Refugee in International Law (Oxford: Clarendon Press, 1996)

Goodwin-Gill G. Refugees and their Human Rights (RSC Working Paper No. 17 Queen Elizabeth House International Development Centre University of Oxford, 2004)

Goodwin-Gill G. and Lambert H. (eds) The Limits of Transnational Law - Refugee Law, Policy Harmonization and Judicial Dialogue in the European Union (Cambridge: Cambridge University Press, 2010) 
GoP/GoA/UNHCR (2003) Agreement between the Government of the Islamic Republic of Pakistan, the Transitional Islamic State of Afghanistan and the United Nations High Commissioner for Refugees Governing the Repatriation of Afghan Refugees Living in Pakistan available at http://www.unhcr.ch/cgibin/texis/vtx/home/opendoc.pdf?tbl=SUBSITES\&page=SUBSITES\&id=3f5d97524

Accessed 26/11/2005.

Gopalakrishnan R. The Geography and Politics of Afghanistan (New Delhi: Concept 1982)

Gul Khattak S. IN/SECURITY Afghan Refugees and Politics in Pakistan (Islamabad: SDPI Working Paper Series, 2003)

Hardy C., 'Refugee Determination: Power and Resistance in Systems of Foucauldian Power' (2003) Administration and Society, 35(4), 462

James C Hathaway and R Alexander Neve, 'Making International Refugee Law Relevant Again: A Proposal for Collectivized and Solution-Oriented Protection' (1997) Harvard Human Rights Journal, 115

Hörnqvist M., Risk Power and the State after Foucault (Abingdon: Routledge 2010)

HRCP - Human Rights Commission of Pakistan Afghan Refugees in Paksitan: When Push comes to Shove (2009) Report available at http://www.hrcp-web.org/pdf/RRefugees.pdf

HRW -Human Rights Watch No safe refuge: the impact of September 11 attacks on refugees, asylum seekers and migrants in the Afghanistan region and worldwide. (2001) Report available at http://repository.forcedmigration.org/show_metadata.jsp?pid=fmo:5417 Accessed $24 / 11 / 2005$

HRW Afghanistan, Iran, and Pakistan. Closed Door Policy: Afghan Refugees in Pakistan and Iran (2002) Available at http://hrw.org/reports/2002/pakistan/ Accessed 24/11/2005.

Hunt A. and Wickham G. Foucault and Law: Towards a Sociology of Law and Governance. (London: Pluto Press, 1994)

Janata A. "Afghanistan: the Ethnic Dimension" in Anderson E.W. and Hatch Dupree N. (eds) The Cultural Basis of Afghan Nationalism (London: Pinter, 1990), 60-70.

Kansi A. The Legal Status of Afghan Refugees. (2003) Unpublished personal notes

Kronenfeld D. 'Afghan Refugees in Pakistan: Not All Refugees, Not Always in Pakistan, Not Necessarily Afghan?’ Journal of Refugee Studies (2008) 21 (1), 43

Lambert H. 'International Refugee Law: Dominant and Emerging Approaches', in David Armstrong (ed.), Handbook of International Law (Oxon: Routledge, 2009):344

Lauterpacht E. and Bethlehem D., 'The Scope and Content of the Principle of Nonrefoulement' in E. Feller, V. Türk, and F. Nicholson (eds) 'Refugee Protection in International Law' UNHCR's Global Consultations on International Protection (Cambridge: Cambridge University Press, 2003): 78-177.

Lemke T., "The Birth of Bio-Politics - Michel Foucault's Lecture at the Collège de France on Neo-Liberal Governmentality" (2001) Economy \& Society 30(2), 190

Lippert, R. Governing Refugees: The Relevance of Governmentality to Understanding the International Refugee Regime (1999) Alternatives 24, 295

Macleod, E. Review of Afghanistan Situation Final Report submitted to the agreement signed between UNHCR and DFID in September 2000. (2001) Islamabad. 
Malik S., 'Refugee Rights under International Jurisdiction: A Case Study of Afghan Refugees' (2005) IPRI Journal, V(1) Available at http://ipripak.org/journal/winter2005.shtml accessed 26 December 2011

Mansfield N., 'Derrida, Democracy and Violence' (2011) Studies in Social Justice 5(1), 231

Marwat F., From Muhajir to Mujahid. Politics of War through Aid. (2004) Peshawar Study Center, University of Peshawar. Available at http://www.bktrc.org/books/marwat/

Mezzadra S., Nielson B. Borderscapes of Differential Inclusion: Subjectivity and Struggles on the Threshold of Justice's Excess in E. Balibar S. Mezzadra R. Samaddar (eds) The Borders of Justice (Philadelphia: Temple University Press, 2012), 181-204.

Miller P. and Rose N. "Governing economic life" (1990) Economy and Society 19(1), 1

Morgan Wortham S. The Derrida Dictionary (London: Continuum Books, 2010)

Munro V., Legal Feminism and Foucault - A Critique of the Expulsion of Law. (2001) Journal of Law and Society 28(4): 546-567

Novak P. Place and Afghan Refugees. A Contribution to Turton (2007) Journal of Refugee Studies 20 (4), 551

Novak P. The Flexible Territoriality of the Durand Line (2012) Geopolitics 16(4), 741

Orford A.,. Review Essay: Positivism and the Power of International Law' (2000) Melbourne University Law Review 24, 502

Rabinow P and Rose, N. (eds) The Essential Foucault: Selections from the Essential Works Of Foucault, 1954-1984 (London: New Press, 2003)

Rutinwa B., Prima facie status and refugee protection. (2001) New Issues in Refugee Research Working Paper No. 69 Geneva: UNHCR

Samaddar R. "The Game of Justice" in The Materiality of Politics, Volume 2, Subject Positions in Politics (Anthem Press, 2007), 63-106

Samaddar R. The Emergence of the Political Subject (New Delhi: Sage India, 2010)

Sardie M., Survey on health, Nutritional and Socio-economic Status of Afghan Refugees in NWFP (Islamabad: GoP/UNHCR/AUSTCARE, 1984)

Schöch R., 'Afghan refugees in Pakistan during the 1980s: Cold War politics and registration practice' (2008) UNHCR Working Papers ISSN 1020-747 available at: http://www.unhcr.org/refworld/docid/4c2325650.html

SHARP (Society for Human Rights and Prisoners Aid). Workshop on Human Rights and Refugee Law. September 20, 2002 (2002) Report Compiled by Prof. Sikandar Mehdi and Ms. Cyra Syed. SHARP, Islamabad.

Sinha S. The Long March from the Margins: Subaltern Politics, Justice, and Nature in Postcolonial India. In E. Balibar S. Mezzadra R. Samaddar (eds) (The Borders of Justice. Philadelphia: Temple University Press, 2012), 79-98.

Soguk, N. States and Strangers. Refugees and Displacements of Statecraft (Minneapolis: University of Minnesota Press, 1999)

Turk V. And Eyster E., Strengthening Accountability in UNHCR International Journal of Refugee Law (2010) 22(2), 159

UNHCR Voluntary Repatriation to Afghanistan (2003) Islamabad: UNHCR Pakistan. 
UNHCR Searching for Solutions. 25 years of UNHCR - Pakistan cooperation on Afghan refugees (2004a) Available at http://www.un.org.pk/unhcr/publications.htm, accessed 14Jan2006.

UNHCR "UNHCR Projected Global Resettlement Needs" Annual Tripartite Consultations on Resettlement, Geneva, 18-19 June 2003 (2004c) UNHCR Refworld, Available at http://www.unhcr.org/cgi-

bin/texis/vtx/refworld/rwmain?page=search\&amp;docid=3f40da734\&amp;skip=\&amp;query $=$ UNHCR\%20Projected\%20Global\%20Resettlement\%20Needs\%202004 accessed 15th December 2007.

UNHCR Maintaining the Civilian and Humanitarian Character of Asylum. June 2004 (2004d) available at: http://www.unhcr.org/refworld/docid/413da3644.html

UNHCR Self-Study Module 1: An Introduction to International Protection. Protecting Persons of Concern to UNHCR Online: UNHCR Refworld. (2005) Available at http://www.unhcr.org/refworld/docid/4214cb4f2.html [accessed 16 June 2011]

USCR Afghan Refugees in Pakistan: Shunned and Scorned (Washington: United States Committee for Refugees, 2001)

Weissbrodt G. and Newman F. International Human Rights: Law, Policy, and Process (1990) (Anderson Publishing, 1st ed. 1990, Supp. 1994; 2d ed., 1996) (with Frank Newman)

WFP, A Dialogue with Afghan Refugees in WFP Assisted Camps of NWFP (unpublished) Peshawar: WFP Sub-Office.

WFP/UNHCR Joint Food Supply Assessment Mission to Pakistan and Afghanistan with Donor Participation. Summary Report of Conclusions and Recommendations 28/4 - 12/5 1994. (1994) Islamabad: WFP/UNHCR.

WFP/UNHCR/Intersos Basic Tripartite Agreement between UNHCR/WFP and Intersos on the distribution of food aid commodities in refugees' camp in Barkalay, in Bajaur Agency, NWFP, January-October 2003, (2003) unpublished MS.

Xavier Inda J. Anthropologies of modernity: Foucault, governmentality, and life politics (Oxford: Blackwell 2005)

Zieck M., 'The Legal Status of Afghan Refugees in Pakistan, a Story of Eight Agreements and Two Suppressed Premises' (2008) International Journal of Refugee Law, 20(2), 253 Available at SSRN: http://ssrn.com/abstract=1158234 